\title{
TURKEY AND FREEDOM OF EXPRESSION IN THE LIGHT OF ECHR JUDGMENTS*
}

\author{
Ferzan DURUL ${ }^{16}$
}

\begin{abstract}
Human rights, which are related to humans' being able to realize themselves as honorable beings and to live humanely, reach a mutual agreement on "protecting" and "improving" all humans and states at an ideal level; whereas, they cannot provide stability in practice. Although a number of measures have been taken, both internally and externally, to prevent the violations of human rights, there has been an increase in the number of violations as well as an increase in the variety of those violations. This increase required the establishment of new control mechanisms by all means. European Court of Human Rights emerges to be the judicial body of these control mechanisms. The sphere of influence of the ECHR, which has recently gained popularity and is seen as the final point to bring justice by many citizens, has considerably expanded as a result of the number of members in European Council hitting 47. ECHR is a control mechanism established by European Convention of Human Rights. This study crystallizes the human rights at a conceptual level and statistically analyses a total of 207 judgments (cases) on freedom of expression, which resulted against Turkey in ECHR between the years 1987 and 2011. The data in question have been collected from HUDOC19 (ECHR's own database), and Ministry of Justice's20 database.
\end{abstract}

\section{AİHM KARARLARI IŞIĞINDA TÜRKIYYE VE İFADE ÖZGÜRLÜĞÜ}

\section{$\ddot{O} z$}

İnsanın insanca yaşaması, onurlu bir varlık olarak kendini gerçekleştirebilmesiyle ilintili olan insan hakları, ideal düzlemde tüm insan ve devletlerin "korunması" ve "geliştirilmesi" konusunda mutabakat sağladığ $\breve{1}_{1}$ ancak uygulamada aynı istikrarın gözlenemediği haklardır. Ulusal ve uluslararası ölçekte insan hakkı ihlallerinin önlenebilmesi için pek çok tedbir alınsa da son yıllarda ihlallerin sayılarında artış olduğu gibi, çeşitliliğinde de artış gözlenmektedir. Elbette bu artış yeni denetim mekanizmalarının da kurulmasını zorunlu kılmıştır. Avrupa insan Hakları Mahkemesi, bu denetim mekanizmalarının yargı organı olarak karşımıza çıkmaktadır. Son dönemde, popülaritesi artan ve pek çok ülke vatandaşı tarafindan adaletin bulunacağl son nokta olarak görülen AİHM'nin etki alanı, Avrupa Konseyinin üye sayısının 47'yi bulmasıly birlikte bir hayli genişlemiş̧ir. AİHM, Avrupa İnsan Hakları Sözleşmesiyle oluşturulmuş bir denetim mekanizmasıdır. Bu çalışmada, kavramsal düzlemde İnsan hakları billurlaştırılarak, 1987-2011 yılları arasında AİHM'nde ifade özgürlüğü alanında Türkiye aleyhine sonuçlanan, toplam 207 karar (dava) istatistiksel olarak çözümlenmiştir. Söz konusu veriler, Avrupa İnsan

Hakları Mahkemesinin kendi veri tabanı olan HUDOC' $\tan ^{17}$ ve AdaletBakanlığı'nın veri tabanından ${ }^{18}$ elde edilmiştir.

Anahtar Kelimeler: AİHM, AİHS, İfade Ögürlüğ̈̈, Hak, İnsan Hakları

JEL Kodu: K12, K38, Z00

\footnotetext{
*This study is the outcome of thedoctoral thesis prepared by the author

${ }^{16}$ Dr. ferdurul@hotmail.com, ORCID: 0000-0003-0775-7615

${ }^{17} \mathrm{http} / / /$ hudoc.echr.coe.int/sites/eng/Pages/search.aspx

${ }^{18} \mathrm{http}: / / \mathrm{www}$. inhak.adalet.gov.tr/mevzuat/mevzuat.html

${ }^{19} \mathrm{http} / / /$ hudoc.echr.coe.int/sites/eng/Pages/search.aspx

${ }^{20} \mathrm{http}: / /$ www.inhak.adalet.gov.tr/mevzuat/mevzuat.html
} 
Key Words: ECHR, European Convention of Human Rights, Freedom of Expression, Rights, Human Rights

JEL Code: K19, Y10, Z00

\section{Introduction}

Being described as the rights we have due to the simple fact that we are human, the concept of human rights has become one of the most difficult concepts to elucidate. This difficulty is mainly caused by the huge discrepancy between what kind of an image a concept creates in mind, and how it appears in practice for sure. In other words, the values found in the fabric of a concept, and the values produced by the system we live in do not match. Foremost among the reasons of this gap between "how it is" and "how it should be" is the fact that, as Çotuksöken states, "Concepts do not have a concrete and single reference point in outer world." (Çotuksöken 2010: 23) More precisely, it is the fact that what is called human rights appears "in human relations, in humans' relations with themselves and other humans, with other living creatures, and with the whole world." (Çotuksöken 2010: 23)

At first glance, human rights suggest "the favourable" and "the pleasant" with regards to the protection of humans and their honour, and mentally lay the foundations of "how it should be"; however, they mostly cause disappointment in practice. Considering the implementations all over the world; consuming humans and the values concerning them one by one, appreciating what humans produce more than appreciating humans themselves, and thinking humans as an "agent" instead of "the purpose" in every kind of change and development make the concept of human rights more difficult to explain for sure. Despite all these challenges, human rights, the subject of which are humans, use inalienable rights each individual endowed with as its base. They are also the rights that can be alleged against the state, and demanded from the state on the ground of humans being humans.

\section{The Concept of Human Rights}

In literature, it is possible to discuss several human rights conceptions based on diverse groundings. These conceptions sometimes ground on the doctrine of natural law, and sometimes on positive law. This diversity provides a convenience in identifying the mind and the pencil that create the definitions of human rights from different angles, though it causes inflation in definitions.

Accordingly, all discourses expressing that humans are endowed with these rights because they are human beings (Tezcan - Erdem - Sancakdar - Önok, 2006: 52-53) are actually based on the doctrine of natural law. It is possible to understand the significance of this doctrine in the documents on human rights, which are entirely embodied by a universality claim. The doctrine of natural law dominates the first two articles of the Declaration of the Rights of Man and of the Citizen issued on 3 September 1791, in the wake of the French Revolution. These articles state that all human beings are born equal and free in terms of rights. As mentioned in Article 2, the rights of liberty, property, security, and resistance against pressure are natural rights that cannot be lost due to timeout. ${ }^{21}$

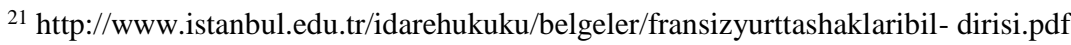


Likewise, almost all statements in the first article of the Virginia Declaration of Rights dated 1776, which has a constitutional value, are also dominated by the same doctrine that considers being born as a human being as a sufficient requirement for human rights.

If one gets to the bottom of this doctrine ideationally, they would actually reach the philosophical ground of human rights. Indeed, human rights are needed for a life of dignity. In a sense, "Human rights theories and documents point beyond actual conditions of existencebeyond the "real" in the sense of what has already been realized - to the possible, which is viewed as a deeper human moral reality. Human rights are less about the way people are than about what they might become" (Donelly, 1989: 29). This is an issue of a life of dignity. No matter what the circumstances are, human dignity merely expresses the recognition of the value gained by being a human.

This behaviour line takes such a turn that each action, or each treatment, dehumanizes individuals in case they fall beneath that line (Güneş, 1998: 915). Thus, human rights adopt a language which implies "how it should be", in other words, "the ideal structure." This discourse, in a sense, is the common goal of humanity without any discrimination of language, religion, race, or sex. It is this point that underlies both internal and external peace.

All these rights enabling humans to live humanely under proper circumstances, to improve themselves, and to be treated humanely arise from this point. When considered in this way, there is no doubt that the ontological foundation of human rights is "the worth of humans that are of most worth"(Uygun 2000: 14). In the light of this analysis, the "morality" forms the basis of the conception of "right" in human rights. Many philosophers deal with this conception in their own definitions of human rights as well. Orend states that:

"A human right is a high-priority claim, or authoritative entitlement, justified by sufficient reasons, to a set of objects that are owed to each human person as a matter of minimally decent treatment." (Erdoğan, 2007:

A right is usually defined as the legal authorization endowed to an individual, and it may rise from the rules of law or the special relationship between these rules. However, as a human, the basis of human rights is hidden in my moral nature. It is surely beyond doubt that the moral nature of humans (Donelly, 1989: 28) hopes for a life of dignity; thus, what makes any right one of the human rights is the dignity owned and demanded by humans, the bearer of this right, in all circumstances. Human rights, in this sense, protect and ensure the human dignity (Gülmez, 2001: 42). For this reason, the basis of human rights is so deep and spiritual (Durul, 2008:8485 ) that this depth, the richness in meaning grant both priority and superiority to human rights against the state, law, and especially community (Donelly, 1989: 28).

American philosopher of law explains how human rights are superior and privileged by using "the trump card metaphor": 


\begin{abstract}
"Just as in certain card games, a trump card beats all others, a rights claim "beats" such competing social values as the growth of the economy, the happiness of the majority...."22
\end{abstract}

On the other side, some ground the superiority of human rights on the positive law conception. The influence of this conception on human rights starts to be seen during the 19th and 20th century in fact, and it concentrates on "how it is" in essence. This conception suggests that the rights in question are the rules of law embodied by humans, and their foundation is not natural, inherent, or originating from God.

\title{
2.1. The Improvement of Human Rights
}

During WWII, remembered with the important changes and transformations it caused, the U.S. president Franklin Roosevelt discussed the "4 Freedoms" 23 in one of the speeches he gave in the United States Congress. These freedoms are: freedom of speech and expression, freedom of religion, freedom from want, and freedom from fear.

The main reason why Roosevelt gave a speech with such a context is the idea that if each individual all over the world owns these rights without any discrimination, it will bring peace, and build human rights on a solid ground.

However, part of the speech the U.S. president Barack Obama gave in the United Nations General Assembly on 23 September 2009, roughly 68 years later Roosevelt gave his speech, is puzzling with regards to human rights.

"Today, let me put forward four pillars that I believe are fundamental to the future that we want for our children: non-proliferation and disarmament; the promotion of peace and security; the preservation of our planet; and a global economy that advances opportunity for all people.

First, we must stop the spread of nuclear weapons, and seek the goal of a world without them. This institution was founded at the dawn of the atomic age, in part because man's capacity to kill had to be contained. For decades, we averted disaster, even under the shadow of a superpower stand-off. But today, the threat of proliferation is growing in scope and complexity. If we fail to act, we will invite nuclear arms races in every region, and the prospect of wars and acts of terror on a scale that we can hardly imagine. A fragile consensus stands in the way of this frightening outcome, and that is the basic bargain that shapes the Nuclear Non-Proliferation Treaty. It says that all nations have the right to peaceful nuclear energy; that nations with nuclear weapons have a responsibility to move toward disarmament; and those without them have the responsibility to forsake them. The next 12 months could be pivotal in determining whether this compact will be strengthened or will slowly dissolve." ${ }^{24}$

\footnotetext{
${ }^{22}$ http://www.ihb.gov.tr/Yayinlarimiz/insan_haklari_kitabi_LOW.pdf (Date of Access: 11 November 2008)

${ }^{23} \mathrm{http}: / /$ www.dusuncetarihi.com/makale/dort-ozgurluk-soeylevi (Date of Access: 11 January 2011)

${ }^{24} \mathrm{http} / / / \mathrm{www}$. ikincigrup.com/index.asp?haberID=28462 (Date of Access:24.08.2011)
} 
This statement depicts the distance covered during the intervening 68 years. The result is quite obvious: these " 4 freedoms" form an idea which is needed to be realized for the sake of humanity in the minimum basis, but it is clearly understood this goal is extremely difficult to reach due to the development of technology.

The outcome of WWII and Roosevelt's speech about the four freedoms are the cornerstones of the formation of the United Nations. With such cornerstones, the Charter of the United Nations was signed on 26 June 1945. Having come into force on 24 October 1945, the charter, consisted of 110 articles, was signed by roughly 50 nations-later increased to 192 . When looked carefully, it comes to light that the statements found in the beginning part of the charter emphasize how protecting human rights and freedoms is highly important for bringing peace to the world, although they were actually adverted to deliver the founding purpose of the UN. Accordingly, these statements indicate that all signatory states will not only respect human rights and freedoms, but also, most importantly, they will prevent the violation of human rights:

"We the peoples of the United Nations determined to save succeeding generations from the scourge of war, which twice in our lifetime has brought untold sorrow to mankind, and to reaffirm faith in fundamental human rights, in the dignity and worth of the human person, in the equal rights of men and women and of nations large and small, and to establish conditions under which justice and respect for the obligations arising from treaties and other sources of international law can be maintained, and to promote social progress and better standards of life in larger freedom, and for these ends to practice tolerance and live together in peace with one another as good neighbours, and to unite our strength to maintain international peace and security, and to ensure, by the acceptance of principles and the institution of methods, that armed force shall not be used, save in the common interest, and to employ international machinery for the promotion of the economic and social advancement of all peoples." 25

Having come into existence with this charter, the United Nations--as in League of Nations established to find peaceful solutions to problems that are likely to arise between nations after WW1--was established to avoid new wars, bring peace to the world, and protect human rights (Anar, 1999:33). Today, the UN's aim and scope are not limited with these. The wide range of tasks include many areas such as child welfare and development, environmental issues, poverty reduction, economic and agricultural development, women's rights, and use of atomic energy for peaceful purposes ${ }^{26}$.

The biggest success of the UN is the Universal Declaration of Human Rights prepared during the meetings of UN General Assembly in 1948 in order to give a universal meaning to human rights all over the world, and determine the ideal criteria.(see Annex 1) The reason underlying the Declaration is the fact that there are not any lists in which human rights are named one by one, although the United Nations Charter consists of 110 articles. The Universal Declaration of Human Rights was established with this necessity, and it is a highly comprehensive declaration with its 30 articles in total--including the introduction part. This declaration, accepted and declared by the UN General Assembly, does not have any sanction power; but it had a certain influence all over the world.

\footnotetext{
${ }^{25} \mathrm{http}: / /$ www.tbmm.gov.tr/komisyon/insanhaklari/pdf01/3-30.pdf

${ }^{26}$ http://www.un.org.tr/ (Date of Access: 24 March 2011)
} 
As a matter of fact, it was voted by 56 members $^{27}$ in total, and accepted (Gemalmaz, 2001: 314) with 48 yes and 8 abstain $^{28}$. This declaration has been translated into over 360 languages (Aybay, 2010:43). It does not have any sanction power, because the present text has an ethical quality, not a judicial quality.

When all articles considered, it is possible to think that the declaration uses more of a precatory language. It reveals the minimum limit of the living conditions that are necessary for the humanity to live humanely, and states, especially in the introduction part, that the goal is to ensure all individuals, nations and societies are able to reach that target. Therefore, it is not too wrong to say that this declaration is an ethical declaration, more importantly, "a speech-act realized by the international community with utmost care," (Kuçuradi 2004:14) although it does not have any sanction power legally.

Historically, the United Nations has worked on a range of covenants and conferences with the aim of shaping human rights at a universal level, moving these rights with a different discourse from the ideal area to the real, and more importantly, laying the foundations of the international cohesiveness of the Universal Declaration of Human Rights articles. These rights are respectively:

- International Covenant on Civil and Political Rights ${ }^{29}$

- International Covenant on Economic, Social and Cultural Rights ${ }^{30}$

- International Convention on the Elimination of All Forms of Racial Discrimination ${ }^{31}$

- Convention on the Elimination of All Forms of Discrimination against Women ${ }^{32}$

- Convention against Torture and Other Cruel, Inhuman or Degrading Treatment or Punishment ${ }^{33}$

\footnotetext{
${ }^{27}$ Fifty-eight states that were members of the UN during this period are: Argentina, Australia, Belgium, Bolivia, Brazil, Belarus, Canada, Chile, China, Colombia, Costa Rica, Cuba, Czechoslovakia, Denmark, Dominican Republic, Ecuador, Egypt, El Salvador, Ethiopia, France, Greece, Guatemala, Haiti, Honduras, India, Iran, Iraq, Lebanon, Liberia, Luxembourg, Mexico, Netherlands, New Zealand, Nicaragua, Norway, Panama, Paraguay, Peru, Philippines, Poland, Soviet Union, Saudi Arabia, South Africa, Syrian Arab Republic, Turkey, Ukraine, United Kingdom and Northern Ireland, United States, Uruguay, Bolivarian Republic of Venezuela, Yugoslavia, Afghanistan, Iceland, Sweden, Thailand, Pakistan, Yemen, Myanmar. For the number of UN members in the historical process, see (Online) http://www.un.org/Overview/growth.htm\#40, 20 September 2006.

${ }^{28}$ The USSR, Poland, Yugoslavia, Czechoslovakia, Belarus, Ukraine, Saudi Arabia and the South

African Union abstained.

${ }^{29}$ The International Covenant on Civil and Political Rights was ratified by the UN General Assembly with the resolution 2200 A (XXI) on 16 December 1966, and was put into effect after its ratification by 35 countries on 23 March 1976.

(http://www. belgenet.com/arsiv/bm/bmsiyasihak.html (Date of Access: 2 Ağustos 2011)

${ }^{30}$ This Covenant was ratified by the UN General Assembly on 16 December 1966 with the Resolution $2200 \mathrm{~A}$ (XXI) and was opened for signature, approval and accession. It entered into force on 3 January 1976, with the approval of 35 states. (http:// www. belgenet.com/arsiv/bm/bmsiyasihak.html (Accessed on 2 August 2011)

31 The International Convention on the Elimination of All Forms of Racial Discrimination was unanimously accepted by the United Nations General Assembly on 21 December 1965, and was opened for signature on 7 March 1966. Entered into force on 4 January 1969. (http://www.belgenet.com/arsiv/bm/bmsiyasihak.html (Accessed on 2 August 2011)

32 This Convention was accepted by the UN General Assembly on 18 December 1979 with the Resolution $34 / 180$, and opened for signature. It came into force on September 3, 1981 with the approval of 20 states. (http://www.unicef.org/turkey/cedaw/_gi18. html) (Accessed on 2 August 2011)

33 The Convention against Torture and Other Cruel, Inhuman or Degrading Treatment or Punishment was accepted by the UN General Assembly in 1984 with the Resolution 39/46. (http://www.un.org/documents/ga/res/39/ a39r046.htm (Accessed on 2 August 2011)
} 
- Convention on the rights of the children ${ }^{34}$

- International Conference on Human Rights in Tehran, 1965

- World Conference on Human Rights in Vienna on 14 to 25 June 1993

All of these covenants use "the state parties have agreed" expression to hold all states that have signed the covenant and established certain universal criteria to certify the universality of human rights liable. The universality and necessity of human rights was mentioned once again in Article 2 of the Proclamation of Tehran, which was adopted on 13 May 1968, right after the International Conference on Human Rights in Tehran. According to this article, "The Universal Declaration of Human Rights states a common understanding of the peoples of the world concerning the inalienable and inviolable rights of all members of the human family and constitutes an obligation for the members of the international community." 35

The Vienna Declaration and Programme of Action adopted by the World Conference on Human Rights in Vienna on 25 June 1993 also acutely emphasizes that human rights are an issue of high priority and importance all over the world, and most importantly, it goes through the universal protection mechanisms (Ünal, 1997: 126). This declaration confirms and legalizes the universality of human rights:

"All human rights are universal, indivisible and interdependent and interrelated. The international community must treat human rights globally in a fair and equal manner, on the same footing, and with the same emphasis. While the significance of national and regional particularities and various historical, cultural and religious backgrounds must be borne in mind, it is the duty of States, regardless of their political, economic and cultural systems, to promote and protect all human rights and fundamental freedoms." ${ }^{36}$

These declarations and Covenants were technically adopted to make the Universal Declaration of Human Rights, which was embodied by its emphasis on the universality and positive law, functional. However, just like the Universal Declaration, some of them have been criticized, in terms of their content and scope, on the basis of universality concept.

At this point, while the UN's member states, each with its own life style, rituals and preadmission, were arguing about the UN and Universal Declaration of Human Rights in the context of universality, the European nations which share the same values, history and culture took advantage of their parallel ideologies, and signed a legally binding convention between each other. What lies behind this convention in particular is the Council of Europe which is a regional structure established after WWII.

The European Congress was established in the Hague, 1948, with the participation of deputies from sixteen different European countries, and observers from ten different countries (Özbey, 2008: 13).

\footnotetext{
${ }^{34}$ This Convention was ratified by the UN General Assembly in 20 November 1989 with the Resolution $44 / 25$, and were opened for signature, approval and accession. The Convention entered into force on 2 $\begin{array}{llllll}\text { September } & 1990 & \text { in } & \text { accordance } & \text { with }\end{array}$ (http://www.tbmm.gov.tr/komisyon/insanhaklari/pdf01/137-160.pdf) (Accessed on 2 August 2011)

35 http://www1.umn.edu/humanrts/instree/12ptichr.htm (Accessed on 25 May 2012)

${ }^{36} \mathrm{http}: / /$ www.unhchr.ch/huridocda/huridoca.nsf/(symbol)/a.conf.157.23.en (Accessed on 18 April 2012)
} 
What could possibly be the most significant output of this congress is the Council of Europe. Within this period, ten European countries ${ }^{37}$ gathered in London, 1949, and signed the Statute of the Council of Europe. ${ }^{38}$ Democratisation, state of law, human rights and peace are the concepts crystallised within the main purpose of the $\mathrm{CoE}$ which was embodied by this statute. The Council, however, attracted more attention in the area of activity related to human rights, and approached the human rights concept as a goal and value that unites, especially, Western Europe (Özdek 2004: 10). One of the most significant conventions the Council has signed is the European Convention on Human Rights (see Annex 2).

This convention is known as "European Convention on Human Rights," whereas, its full name is "Convention for the Protection of Human Rights and Fundamental Freedoms" (see Annex 2). Having been embodied considering the 1948 Universal Declaration of Human Rights in historical context, the convention's aim can be clearly seen in the beginning sentences:

"...Considering that the aim of the Council of Europe is the achievement of greater unity between its members and that one of the methods by which that aim is to be pursued is the maintenance and further realisation of Human Rights and Fundamental Freedoms; reaffirming their profound belief in those fundamental freedoms which are the foundation of justice and peace in the world and are best maintained on the one hand by an effective political democracy and on the other by a common understanding and observance of the Human Rights upon which they depend; being resolved, as the governments of European countries which are like-minded and have a common heritage of political traditions, ideals, freedom and the rule of law, to take the first steps for the collective enforcement of certain of the rights stated in the Universal Declaration." 39

The convention was signed in Rome on 4 November 1950, but only came into force on 3 September 1952.

The signatory nations are obliged to give the rights and freedoms mentioned in the convention to each individual under their rule, and accommodate every regulation of their domestic law to the European Convention on Human Rights. Thus, the convention is considered as the Constitution for Europe (Frowein, 1992: 111). The chief point here is the obligations of signatory nations are not only limited to their own territories, but these nations also promise to build and protect, within their area of responsibility, the rights and freedoms in the ECHR. This promise is valid in every area in which these nations have "actual power" (Gemalmaz, 2010: 369)

The European Convention on Human Rights is a threefold convention that consists of 59 articles. The convention has undergone many changes since the date it was approved, 1950; and, with 14 additional protocols, its content as well as several control mechanisms have been activated.

The first article of the European Convention on Human Rights, denoted for respecting human rights, makes the obligations of signatory nations to assure the rights and freedoms in question a current issue.

\footnotetext{
${ }^{37}$ These 10 Western countries are Belgium, France, Luxembourg, the Netherlands, the UK, Denmark, Norway, Ireland, Italy and Sweden.

${ }^{38} \mathrm{http}: / /$ www.mfa.gov.tr/avrupa-konseyi_.tr.mfa (Accessed on 10.10.2012)

${ }^{39} \mathrm{http} / / /$ www.anayasa.gov.tr/files/bireysel_basvuru/AIHS_tr.pdf (Accessed on 21 March 2011)
} 
First section of the convention named as "Rights and freedoms," between Article 2 and 18, deals with the rights and freedoms that are assured; whereas, the second section deals with the European Court of Human Right's establishment and operation (see Annex 2, Articles 19-52). The last section named as "Miscellaneous provisions," however, includes the regulations in the area of the convention's entry into force and implementation (see Annex 2, Articles 52-59).

The rights mentioned in the convention are listed like this:

Right to life (Article 2)

Prohibition of torture (Article 3)

Prohibition of slavery and forced labour (Article 4)

Right to liberty and security (Article 5)

Right to a fair trial (Article 6)

No punishment without law (Article 7)

Right to respect for private and family life (Article 8)

Freedom of thought, conscience and religion (Article 9)

Freedom of expression (Article 10)

Freedom of assembly and association (Article 11)

Right to marry (Article 12)

Right to an effective remedy (Article 13)

Prohibition of discrimination (Article 14)

Rights included to the Convention with Protocol No. $\mathbf{1}^{40}$;

Protection of property (Article 1)

Right to education (Article 2)

Right to free elections (Article 3)

Rights included to the Convention with Protocol No. $4^{41}$;

Prohibition of imprisonment for debt (Article 1)

Freedom of movement (Article 2)

Prohibition of expulsion of nationals (Article 3)

Prohibition of collective expulsion of aliens (Article 4)

Rights included to the Convention with Protocol No. $7^{42}$;

Procedural safeguards relating to expulsion of aliens (Article 1)

Right of appeal in criminal matters (Article 2)

Compensation for wrongful conviction (Article 3)

\footnotetext{
${ }^{40}$ It was signed in Paris in March 1952 and entered into force on 18 March 1954.

${ }^{41}$ It was signed on 16 September 1963 and entered into force on 2 May 1968.

${ }^{42}$ It was signed on 22 November 1984 and entered into force on 11 January 1998.
} 
Right not to be tried or punished twice (Article 4)

Equality between spouses (Article 5)

Apart from this, the Protocol No. 6, which was opened for signature on 28 April 1983 in Strasbourg and which came into force on 1 March 1985, revoked the "death penalty" except for limited cases. The "death penalty" was revoked in all cases by the Additional Protocol No. 13 dated May 2002.

This is not the only significance of ECHR, in which the rights are explained in detail, and concrete restrictions are imposed. Another important aspect of this Convention is the control mechanism (Kapani, 1976: 45) established to ensure the protection of rights and freedoms. This control mechanism was divided into three groups before the Protocol No. 11 came into force, and these three mechanisms were called "Commission of Human Rights" (1954), "Court of Human Rights" (1959), and "Committee of Ministers." However, with the Protocol No. 11, which came into force on 1 November 1998, the Commission and the Court were replaced by a single, full-time Court to ensure the rapid functioning of the control mechanism. Furthermore, the judicial power of the Committee of Ministers, which was a political decision-making body in the convention, was terminated (Özdek, 2002: 30).

It was when the European Court of Human Rights became the most important control mechanism in the convention as the one and only court.

\section{European Court of Human Rights}

With the Protocol No. 11 of the convention, the European Court of Human Rights and the European Commission of Human Rights were terminated, and in their places, a single court, that is the European Court of Human Rights, has been established; therefore, the Court has become the single and most important body, especially within the ECHR ( Ergül, 2004: 13).

Article 19 of the ECHR explains the Court's founding purpose in this way: "To ensure the observance of the engagements undertaken by the High Contracting Parties in the Convention and the Protocols thereto, there shall be set up a European Court of Human Rights, hereinafter referred to as "the Court". It shall function on a permanent basis" (Reisoğlu, 2001: 167).

The Court's headquarters is the Council of Europe's headquarters in Strasbourg; however, as stated in Article 19/1 of the Rules of Court (see Annex 3), the Court may, if appropriate, designate or change its headquarters as a place within the territory of the Council of Europe's member states.

The Court is composed of as many judges as the number of the ECHR's member states (ECHR, Art. 20) (see Annex 2). These judges shall be elected by the Parliamentary Assembly of the Council of Europe from a list of three candidates to be submitted by each high contracting party of the Convention. ${ }^{43}$ The judges elected here are obliged to perform their duties independently and impartially, even if they are nominated by the contracting states. They are elected for a single term of nine years. The age limit is 70 (Tanrikulu, 2007: 17). If a judge has replaced a judge who has left the office for a number of reasons before the end of his/her term, he/she will complete the term of office of the judge (Doğru - Nalbant, 2001: 1-2).

\footnotetext{
${ }^{43} \mathrm{http} / / /$ www.echr.coe.int/NR/rdonlyres/A6FDF170-5DA0-4F25-8017-

8D49A83681F0/0/TUR_50questions_Web.pdf (Date of Access:10.06.2011)
} 
As stated in Article 26 (a) of the Convention, the Court is obliged to elect a President and a Vice-President. The duties of the President are also discussed in detail in the Rules of Court. The President has certain duties related to the judiciary.

Accordingly, the President shall preside at meetings of the Grand Chamber and meetings of the panel of five judges (Doğru, 1999: 38).

An important division of the Court's basic composition is the Registry of the Court, which consists of the departments established by the Court, an equal number of Registry of Department, and the necessary units to provide the legal and administrative services required by the Court (Rules of Court, Art. 18/1) (see Annex 3).

Finally, the ECHR's judicial bodies are the Committee, the Chamber and the Grand Chamber. Before the Additional Protocol No. 11, this judicial structure of the Court caused the system to function slower; whereas, any application made after this protocol included a three-stage review.

The Committees shall hold a preliminary examination on the admissibility of the applications made, and accordingly, perform the functions such as making an admissibility decision and preparing a report on friendly settlement, or on reporting to the government, or as to the accusations (Durmuş, 2006: 851). The Committees are involved, especially, when personal applications do not require further review, and they hold a screening that enables the system to function faster.

The Chambers of seven judges are perhaps the most important body within the Court's judicial mechanism. If the Committee has not unanimously declared any application inadmissible; the case shall be sent to the Chamber. After this process, the Chamber either concludes that, at the end of the examinations, no further examination of the case is necessary, and issues an inadmissibility decision; or decides on the admissibility. In some cases, they may leave this power in the hands of the Grand Chamber (Özbey, 2008: 87).

The final body within the judicial mechanism is the Grand Chamber, which is the court of first instance to examine the state applications (ECHR, Art. 33). There are only two possible ways for any individual application to come to the Grand Chamber.

The first way is if the case that any Chamber works on cause problems affecting the interpretation of the Convention and its Additional Protocols, or if the solution to the problem contradicts the decision of the Court, the Chamber may leave its jurisdiction in the hands of the Grand Chamber (ECHR, Art. 30, Rules of Court, Art. 72). Here, the Grand Chamber is the court of first instance.

The second way is, under Article 43 of the ECHR, after the decision of the Chamber, the case may be referred to the Grand Chamber with the request of one of the parties. Here, the Grand Chamber is the court of second instance.

It should be kept in mind that the concrete duty of the ECHR in this complex judicial mechanism put in a nutshell here is to examine the complaints of human rights violations, and to decide whether there is any real violation. It examines individual or state applications in terms of compliance with the ECHR and decides accordingly. Most importantly, with regard to Article 46 of the ECHR, the state parties must abide by the decisions made. 


\subsection{Turkey and the European Court of Human Rights}

There have been many applications, especially in recent years, to the ECHR made by Turkey for reasons such as seeking justice, punishment of the country, or the Court's appearing as an appellate court as part of its domestic law. It would not be wrong to say that these applications are mainly based on the South-eastern issue, the State Security Courts and the fair trial. As the vast majority of these applications have resulted against Turkey, Turkey loses prestige in the political arena, and its Human Rights Score falls.

The main purpose of the right to individual application to the Constitutional Court is to reduce the applications to the ECHR. ${ }^{44}$ Perhaps the ECHR's workload has increased for reasons such as the Court's getting more recognition with each passing day, its success in this field, or its being perceived as the last judicial authority. Turkey's share in the workload of the Court is quite perceivable. First of all, the high number of the applications made against Turkey and the decisions concerning Turkey does not only place us in the first place among the countries that keep the Court engaged, but it also reveals clearly that we are on the same rank in the violation of human rights. From time to time, it is argued that a number of decisions against Turkey are given by the Court without being investigated for certain political reasons, and that the empty files are filled at the desk and virtual incidents are created. Moreover, it will not be easy to illuminate the reality behind these incidents while making news. In the newspapers of the period, it was reported that the ECHR financed the terrorism and applied double standard by claiming high compensation amounts for the cases concerning the terrorist organization, but demanding "settlement" between the religionist. There is a naked truth despite everything: as of December 2011, 15.950 of 151.600 pending applications in the ECHR have been made against Turkey. Turkey ranks second after Russia in the applications to be decided. ${ }^{45}$

According to the Annual Report 2011 of the European Court of Human Rights, the number of applications made against Turkey is increasing every year. The distribution of the applications against Turkey by years is as follows:

\footnotetext{
${ }^{44}$ http://www.yargitay.gov.tr/abproje/belge/dagitim/66_Soruda_Bireysel_Bas- vuru.pdf (Date of access: 01.09.2012)

${ }^{45}$ http://www.ihb.gov.tr/dosyagoster.ashx?id=291 (Date of access: 29 Mayıs 2012)
} 


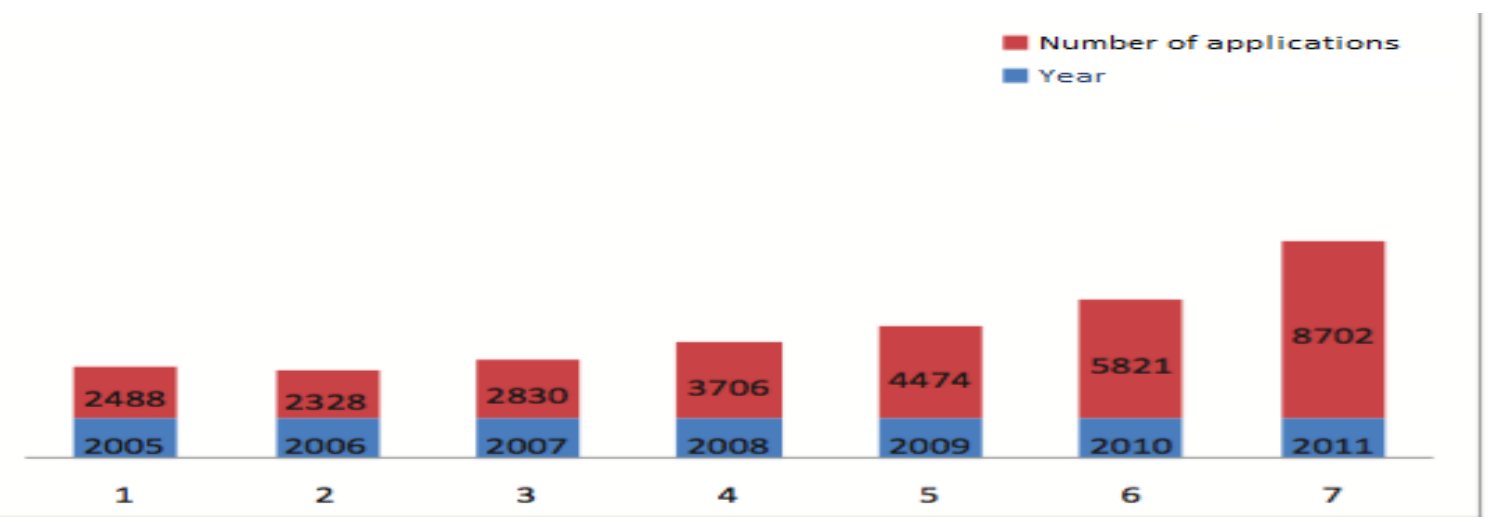

Figure 1. The numeric distribution of the applications against Turkey by years

It is clearly seen that this is not very promising for Turkey. If it is considered that some of the applications could not exceed the admissibility criteria and were excluded from the list for various reasons, the number of decisions made for Turkey, as of 31 December 2011, is 2747. Considering the distribution of decisions ${ }^{46}$, it could be said that they were resulted against Turkey:

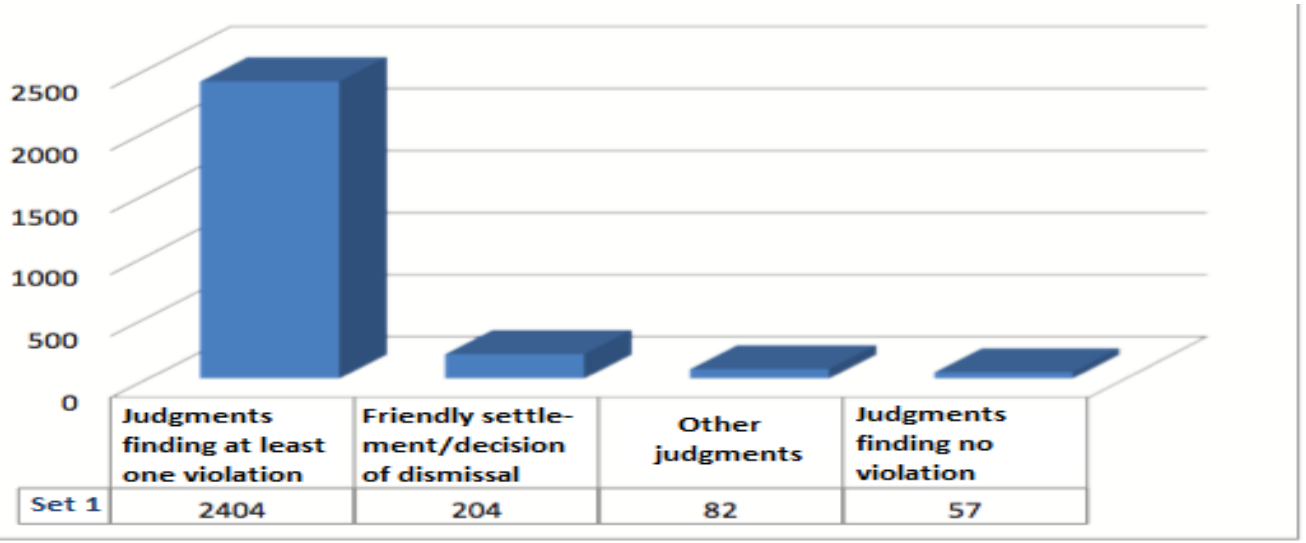

Figure 2. The distribution of 2747 decisions made for Turkey, 1959-2011

Each application resulted against Turkey recalls that the violations have been made and, considering Turkey's circumstances, a high amount of compensation has to be paid. Understanding Turkey in the light of the ECHR will be only possible by looking at both sides of this dramatic picture. When the compensations, especially since 2004, paid by Turkey in return for the violations are considered, the situation is as follows: ${ }^{47}$

22 million 227 thousand 431 TL in 2014

\footnotetext{
${ }^{46} \mathrm{http}: / /$ www.inhak.adalet.gov.tr/istatistikler/2011_ist/03.pdf (Date of access: 25 March 2012)

${ }^{47} \mathrm{http} / / / w w w . h u k u k i ̂ h a b e r . n e t / e k o n o m i / 2011$-aihm-faturasi-37-milyon- tl-h23328.html (Date of access:

10 March 2012
} 
16 million 218 thousand $875.48 \mathrm{TL}$ in 2005

13 million 847 thousand $145.88 \mathrm{TL}$ in 2006

26 million 221 thousand 833.85 TL in 2007

10 million 391 thousand $440.84 \mathrm{TL}$ in 2008

11 million 662 thousand 799.72 TL in 2009

33 million 99 thousand $333.12 \mathrm{TL}$ in 2010

37 million 137 thousand $69.80 \mathrm{TL}$ in 2011

In terms of the compensation amounts paid by Turkey, there are two different drawbacks that are noteworthy. Firstly, the numbers increasing incrementally each year means that violations are also increasing in Turkey, thus, the image of the country is being tarnished as it is perceived as an anti-democratic country. Secondly, the high compensation amounts affect the country's budget negatively.

On the other hand, the legal aspect of the situation is as crucial as its economic aspect. Each decision that determines the violation puts Turkey under an obligation. Like all state parties, Turkey is also liable to execute the ECHR decisions. Making new arrangements and improvements in domestic law in accordance with the decisions is of great importance. Turkey must decide, again by considering the distribution of violations ${ }^{48}$, which articles of the Convention it fails to satisfy, what kind of improvements it needs to make in domestic law with regard to these articles, and which area of human rights it needs to adjust.

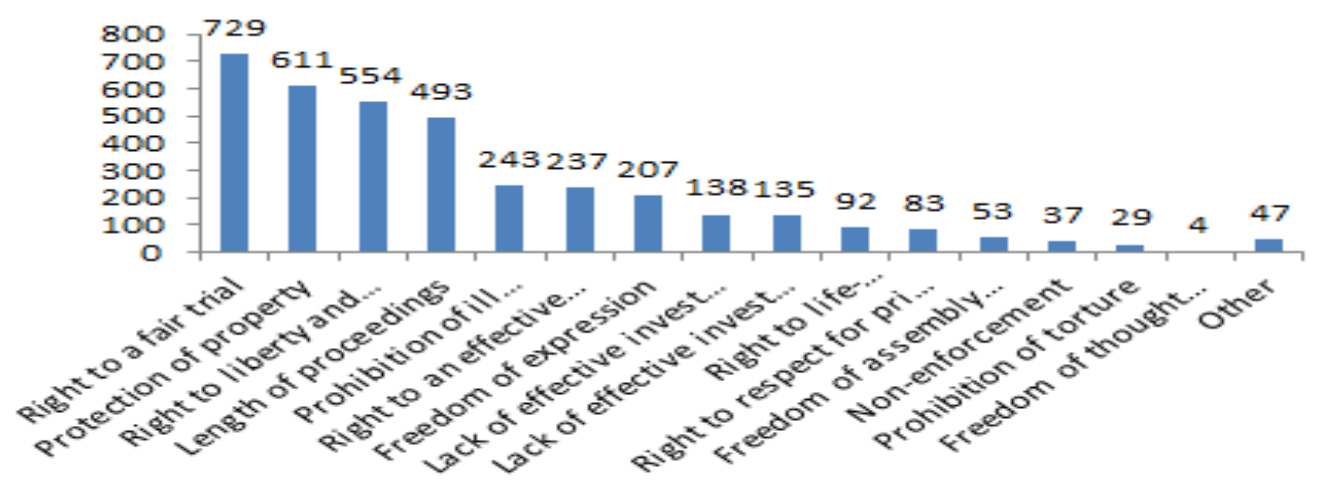

Figure 3. The distribution of violations, 1959-2011

\subsection{Analysis of Turkey in the ECHR Decisions Relating to Freedom of Expression:}

The Court, in its annual report prepared in $2012^{49}$, has set the number of decisions on Turkey's violation of rights in the field of freedom of expression as 207. These 207 decisions were reached via HUDOC and it was found that these 207 decisions (cases) contained 260 files, in other words, references.

\subsubsection{Persons}

\footnotetext{
${ }^{48} \mathrm{http} / / / \mathrm{www}$. inhak.adalet.gov.tr/istatistikler/2011_ist/04.pdf (Date of access: 19 May 2012)

${ }^{49} \mathrm{http}: / /$ echr.coe.int/Documents/Annual_report_2012_ENG.pdf
} 
The total number of plaintiffs in the 207 cases is 566 . While $97.5 \%$ of these plaintiffs are real persons, $2.5 \%$ of them are legal persons. The distribution of these persons by gender is as follows:

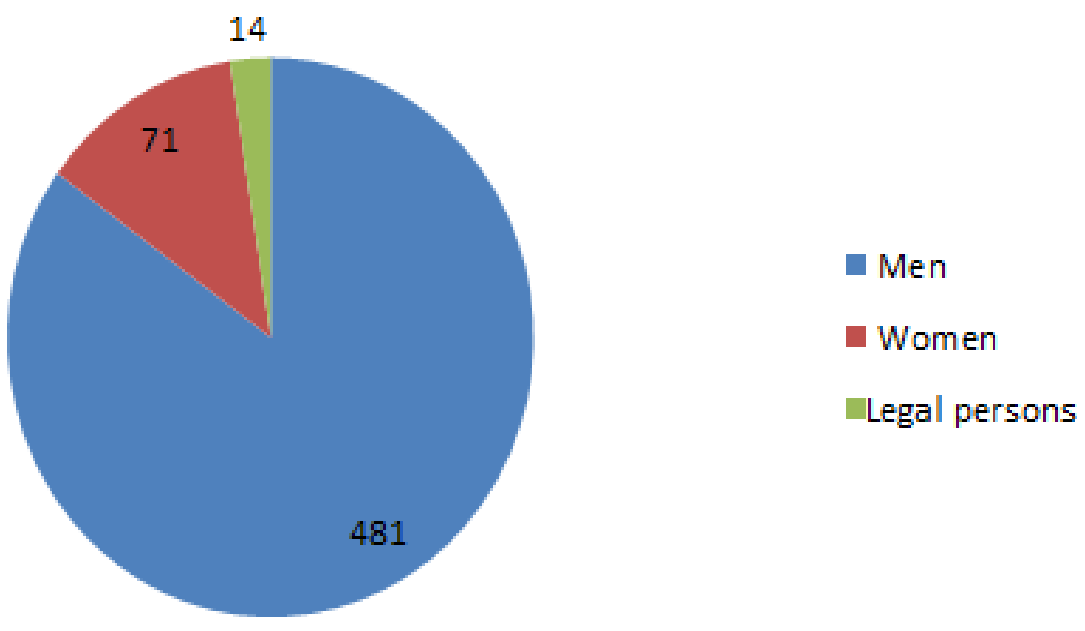

Figure 4. The gender distribution of plaintiffs in ECHR decisions made for Turkey on the violation of freedom of expression

As it can be seen, $85 \%$ of the applicants are male, $12.5 \%$ are female and $2.5 \%$ are legal persons. When the ECHR cases in the area of freedom of expression that were determined as a violation of Article 10 are examined with a gender perspective, it is seen that the people who react against any article, speech, and even any incident or situation are mainly men.

The occupations of the real persons (566 people in total) that applied to the ECHR in these cases are as follows:

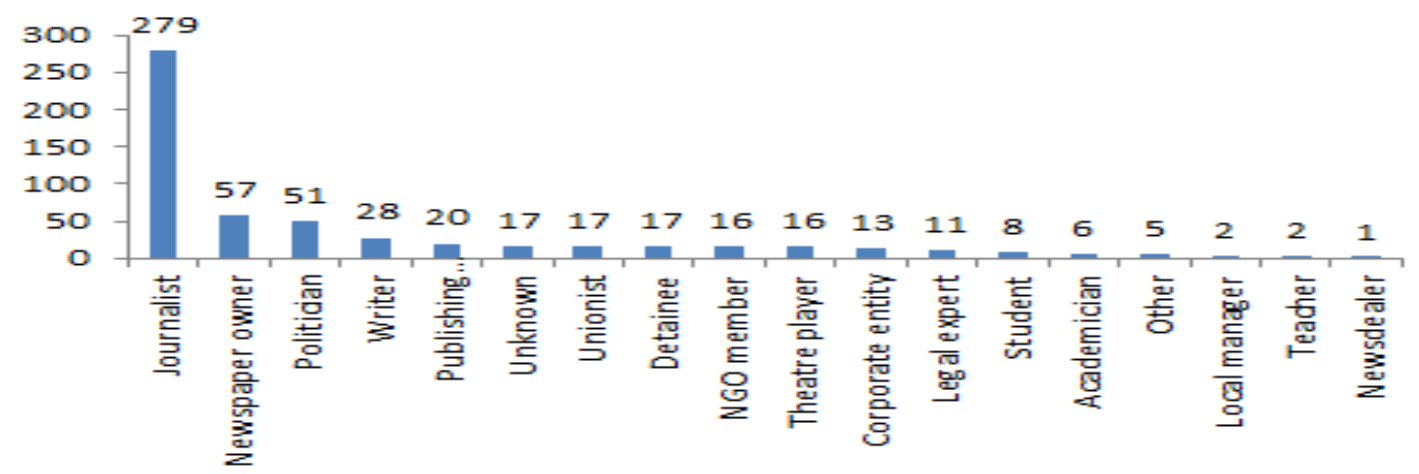

Figure 5. The occupational distribution of plaintiffs in ECHR decisions made for Turkey on the violation of freedom of expression, 1959-2011 
It can easily be said that journalists, newspaper owners and politicians are predominant.

The political parties with which these politicians are affiliated are as follows:

Table 1. The distribution of political parties with which the politicians are affiliated

\begin{tabular}{l|r|} 
Political parties & Number of people \\
\hline HADEP(Peoples' democratic party) & 13 \\
\hline HEP(People's labour party) & 10 \\
\hline DEP(Democracy party) & 8 \\
\hline BDP(Peace and democracy party) & 5 \\
\hline EMEP(Labour party) & 5 \\
\hline ÖDP(Freedom and solidarity party) & 3 \\
\hline YDP(Renaissance party) & 2 \\
\hline SP(Socialist party) & 1 \\
\hline RP(Welfare party) & 1 \\
\hline DEHAP(Democratic people's party) & 1 \\
\hline ANAP(Motherland party) & 1 \\
\hline HAK-PAR(Rights and freedoms party) & 1 \\
\hline TOTAL & 51 \\
\hline
\end{tabular}

HADEP closed by the Constitutional Court of the Turkish Republic on 13 March 2013 on the grounds that it was "the centre of illegal activities" is at the top of the list. When it is considered that the predecessors of HADEP are HEP and DEP, and its successors are DEHAP and BDP, not to mention HAKPAR; it can be said that $74 \%$ of these parties have ideologies shaped on Kurdish Nationalism. On the other hand, the ratio of ÖDP, YDP and Socialist Party, which defined their political positions as left or extreme left, and their ideologies as socialism and Marxism, was determined as $21 \%$.

When we look at the institutions the people that are members of Non-Governmental Organizations (16 people) are affiliated with, 7 different NGOs are mentioned. These are respectively:

- Human Rights Associations

- Independent Industrialists and Businessmen's Association (MUSIAD)

- Research Centre for Women's Studies and Solidarity with Kurdish Women

- Freedom to Kurdish Association

- Community Centre Association

- Ankara Democracy Platform

- Tunceli Culture and Solidarity Association

- Families of the Detainee and Sentenced Anatolian Association (TAYAD) 


\subsubsection{Expression Mediums}

In 207 decisions (cases), the expression mediums used by the applicants are as follows:
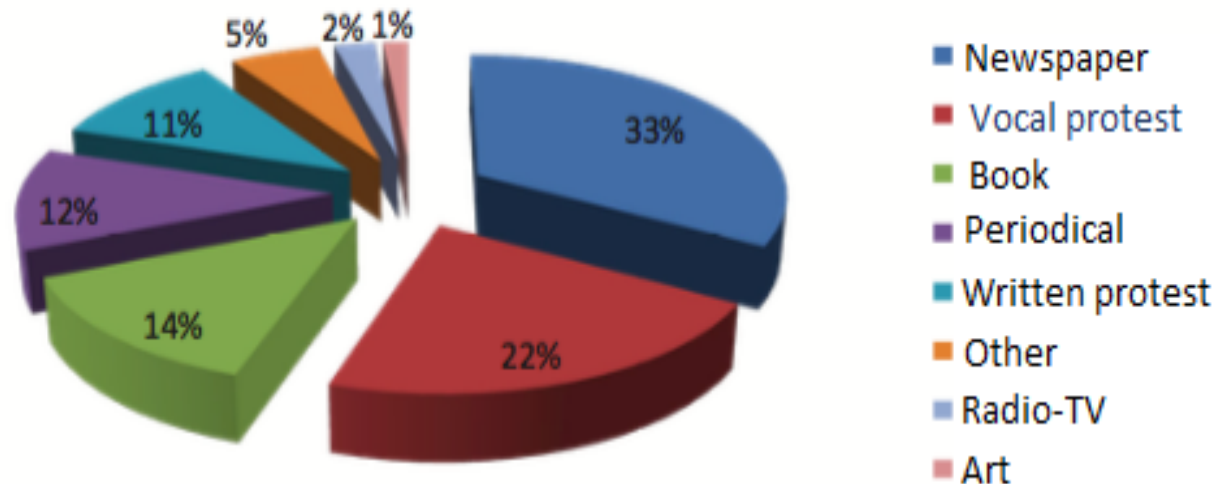

Figure 6. The expression mediums used in ECHR decisions made for Turkey on the violation of freedom of expression

What lies behind the expression mediums used is the typology of the protest concept. According to this typology:

Vocal Protest: Manifest, Protest, Propaganda, Rally, Slogan, Discourse, Celebration

Written Protest: Bulletin, Press Release, Brochure, Declaration, Poster, Issuing a Statement, Banner

Others: Reading Some Periodicals, Letter, Licence Revocation, Insulting the Judge, Party Closure, Complaint, Disciplinary Proceeding

It is clearly seen that newspapers, vocal protests, books and periodicals take the first four places. Nonetheless, the preferred medium of expression is mainly newspapers.

86 out of 260 files are newspaper applications. The distribution of the newspapers in these 86 files by groups is provided in Figure 5-4. 61\% of the files include Kurdish newspapers, and 30\% include left-wing newspapers.

Another noteworthy point here is the fact that 36 different newspaper names are mentioned in 86 different files. However, the existence of different newspaper names here should not be misleading, because 22 of the 36 different newspaper names are the successors of Özgür Gündem (Akyol 2010:100-131).

Apart from that, 29 of 207 cases are related to books. 45 different book names are mentioned in these 29 cases. It can be said that approximately $85 \%$ of these books focus on the Kurdish and South-eastern Question. On the other hand, 17 of these books were published in Istanbul, 27 in Ankara, and 1 in Bandirma. 


\subsubsection{Prime Ministers of the Period}

The heads of governments, i.e. the prime ministers in office at the time of the incidents that were the subject of 207 cases in the ECHR, which resulted against Turkey between 1987 and 2011, and their terms of office are:

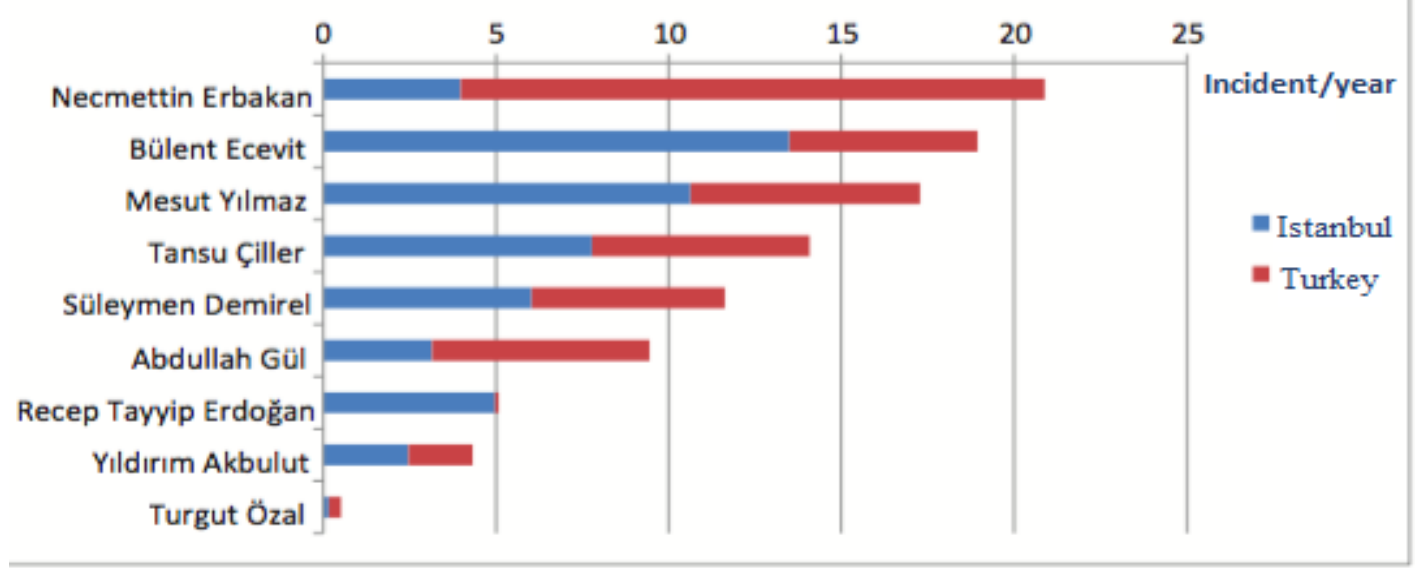

Figure 7. The number of incidents took place during prime ministers term of office

(Standardized with regard to their Terms of Office)

As it is seen, the incidents which were the subject of the cases mostly occurred during Necmettin Erbakan (54th Government) period and least occurred during Turgut Özal (1st and 2nd Özal Government) period.

The distribution of the incidents took place during their term of office by the mediums of expression is as follows:

Table 2. The distribution of incidents took place during prime ministers' term of office by the mediums of expression (Standardized with regard to their Terms of Office)

\begin{tabular}{|c|c|c|c|c|c|c|c|c|c|}
\hline $\begin{array}{l}\text { Prime } \\
\text { ministers }\end{array}$ & Periodicals & Newspapers & Books & Radio-TV & Art & $\begin{array}{l}\text { Vocal } \\
\text { Protest }\end{array}$ & $\begin{array}{l}\text { Written } \\
\text { Protest }\end{array}$ & Other & Total \\
\hline Abdullah Gül & 3,1 & & & & & 6,3 & & & 9,4 \\
\hline Bülent Ecevit & 1,8 & 9,1 & 1,3 & 1,6 & ? & 1,6 & 1,6 & 1,6 & 18,9 \\
\hline Mesut Yilmaz & 0,4 & 6,6 & 2,7 & 0,4 & & 4,9 & 2,2 & & 17,3 \\
\hline $\begin{array}{l}\text { Necmettin } \\
\text { Erbakan }\end{array}$ & 1,0 & & 4,0 & & $\overrightarrow{0}$ & 9,0 & 5,0 & 1,0 & 20,9 \\
\hline $\begin{array}{l}\text { Recep Tayyip } \\
\text { Erdop̃an }\end{array}$ & & 4,9 & 0,1 & 0,1 & & & & & 5,1 \\
\hline Tansu Ciller & 2,2 & 2,6 & 2,2 & 0,4 & & 3,3 & 1,5 & 1,9 & 14,1 \\
\hline Turgut Özal & & & 0,3 & & & 0,2 & & & 0,5 \\
\hline $\begin{array}{l}\text { Yildırim } \\
\text { Akbulut }\end{array}$ & 1,2 & & 2,5 & & & 0,6 & & & 4,3 \\
\hline $\begin{array}{l}\text { Süleyman } \\
\text { Demirel }\end{array}$ & 3,7 & 1,6 & 1,2 & & & 2,9 & 1,6 & & 11,1 \\
\hline
\end{tabular}




\subsubsection{Compensation Amounts}

When the compensation amounts of 207 ECHR decisions on freedom of expression, which resulted against Turkey between 1987 and 2011, are analysed; it can be seen that in some cases only non-pecuniary damages are stated, in some cases pecuniary and non-pecuniary damages are stated separately, and in other cases pecuniary and non-pecuniary damages are stated in total. The charges and aids are also stated separately. The currencies of these indemnities are US Dollar, French Franc, and British Pounds. When these currencies and amounts are converted to the Dollar exchange rate in 2012, the compensation amounts paid in the total of 207 decisions is as follows:

Table 3. The compensation amounts paid in ECHR decisions on freedom of expression, which resulted against Turkey, 1987-2011

\begin{tabular}{l|l|} 
Compensation type & Compensation (\$) \\
\hline Pecuniary & 312.387 \\
\hline Non-pecuniary & 1.563 .002 \\
\hline Pecuniary+Non-pecuniary & 132.403 \\
\hline Charges and Aids & 445.939 \\
\hline TOTAL & 2.453 .731 \\
\hline
\end{tabular}

When the distribution of these indemnities by provinces is examined, Istanbul is in the first place with $62 \%$, and Ankara is in the second place with $20 \%$.

Newspapers rank first with 39\%, as seen in Table 5-10, according to the compensation amounts paid considering the expression mediums used in the incidents that were the subject of these cases. Considering the year of decision, the compensation amounts paid to these expression mediums are as follows:

Table 4. The distribution of compensation amounts paid in ECHR decisions on freedom of expression, which resulted against Turkey, by expression mediums, 1987-2011

\begin{tabular}{l|l|l|} 
Expression mediums & Compensation (\$) & Compensation (\%) \\
\hline Newspapers & 966.144 & 39 \\
\hline Vocal protest & 519.448 & 21 \\
\hline Books & 304.752 & 12 \\
\hline Periodicals & 203.243 & 8 \\
\hline Written protest & 192.205 & 8 \\
\hline Other & 139.584 & 6 \\
\hline Art & 93.693 & 4 \\
\hline Radio-TV & 34.663 & 1 \\
\hline TOTAL & $\mathbf{2 . 4 5 3 . 7 3 1}$ & $\mathbf{1 0 0}$ \\
\hline
\end{tabular}

The compensation amounts paid considering the expression mediums used in the incidents that were the subject of these case are: 
Table 5. The distribution of compensation amounts (\$)paid in ECHR decisions on freedom of expression , which resulted against Turkey, by year of decision and expression mediums, 1987-2011

\begin{tabular}{|c|c|c|c|c|c|c|c|c|c|}
\hline $\begin{array}{l}\text { Year of } \\
\text { decision }\end{array}$ & $\begin{array}{l}\text { Perio- } \\
\text { dicals }\end{array}$ & $\begin{array}{l}\text { Newrs- } \\
\text { papers }\end{array}$ & Books & $\begin{array}{l}\text { Radio- } \\
\text { TV }\end{array}$ & Art & $\begin{array}{l}\text { Vocal } \\
\text { protest }\end{array}$ & $\begin{array}{l}\text { Written } \\
\text { protest }\end{array}$ & Other & $\begin{array}{l}\text { Grand } \\
\text { Total }\end{array}$ \\
\hline 1998 & & & & & & & 7.612 & & 7.612 \\
\hline 1999 & 39.449 & 25.104 & 105.597 & & & 9.355 & & & 179.506 \\
\hline 2000 & 12.449 & 56.321 & & & & 25.619 & & & 94.388 \\
\hline \multicolumn{10}{|l|}{2001} \\
\hline 2002 & 14.175 & & 8.595 & & & 16.833 & 32.700 & & 72303 \\
\hline 2003 & & 19.400 & 8.043 & 12.961 & & & & & 40.405 \\
\hline 2004 & 21.952 & 18.580 & 23.745 & & & 122.338 & 80.273 & 16.968 & 283.857 \\
\hline 2005 & 68.892 & 71.382 & 60.841 & & & 146.621 & 18.881 & 0 & 366.618 \\
\hline 2006 & 7.673 & 132.718 & 24.991 & 12.248 & & 42.128 & 20.572 & 38.278 & 278.606 \\
\hline 2007 & 9.155 & 38.259 & 6.291 & & 93.693 & 28.251 & 4.889 & 1.397 & 181.936 \\
\hline 2008 & 12.797 & 32598 & & & & 14.430 & 14.680 & 68.591 & 143.095 \\
\hline 2009 & 11.475 & 162.164 & & 9.454 & & 28.221 & 12.599 & & 223.913 \\
\hline 2010 & 5.227 & 409.617 & 3.587 & & & 63.797 & & 14.349 & 496.577 \\
\hline 2011 & & 0 & 63.060 & & & 21.854 & & & 84.914 \\
\hline TOTAL & & & & & & & & & 2.453 .731 \\
\hline
\end{tabular}

Between the years of 1987 and 2011, the year 2010 was the year in which the highest compensation amount was determined in these 207 ECHR decisions on freedom of expression. The total compensation amount is 496,577 dollars. This year was also the year of the highest compensation amounts paid to newspapers.

The prime ministers of the period and the compensation amounts paid during their terms of office are:

Table 6. The distribution of compensation amounts paid in ECHR decisions on freedom of expression, which resulted against Turkey, with regard to prime ministers of the period, 1987-2011

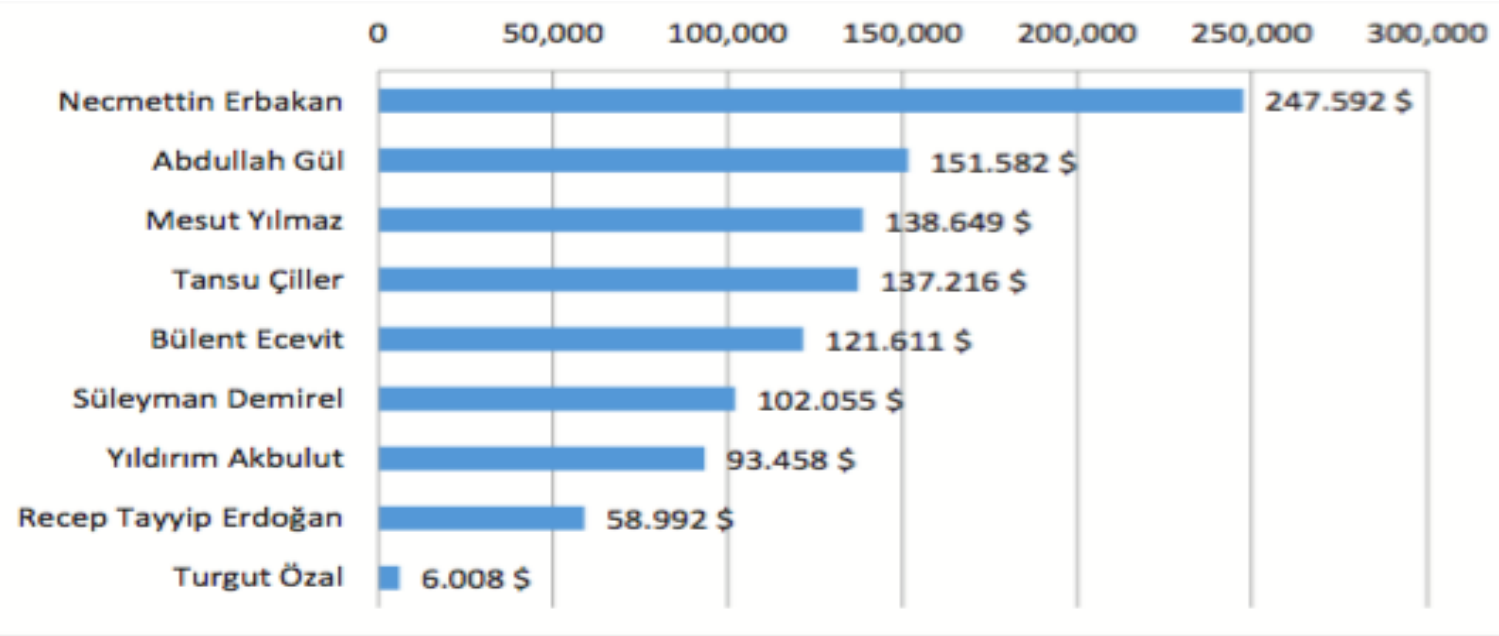

The incident in which the highest compensation amount was paid occurred during Necmettin Erbakan's period, although he had the shortest term of office among other prime ministers; whereas, the lowest compensation amount was paid during Özal's period.

\section{Conclusion}

Turkey became a member of the Council of Europe in 1950, and, as one of the oldest members of the Council, accepted the European Convention on Human Rights in 1954. Turkey's policy of integration with the West in the years 1950-1955 has been very effective in the signing of the Convention. 
Turkey, sometimes by force and sometimes by its own will, has said "yes" to the Convention and all kinds of regulations for a number of political reasons, or accepted the regulations with various reservations in order to keep up with the West. In this process, Turkey accepted the right to make an individual application to the ECHR for the first time in 1987.

There have been many applications, especially in recent years, to the ECHR made by Turkey for reasons such as seeking justice, punishment of the country, or the Court's appearing as an appellate court as part of its domestic law. As the vast majority of these applications have resulted against Turkey, the country loses prestige in the political arena, and its Human Rights Score falls.

If the numerical distribution of freedom of expression cases analysed in this article by countries is observed, the whole picture comes to light. Accordingly, the number of cases in the ECHR that resulted against Turkey between the years 1987-2011 is 207. The total number of cases in the area of freedom of expression that the ECHR concluded between the same years is 479 . It can be said that almost half of the cases are related to Turkey. ${ }^{50}$

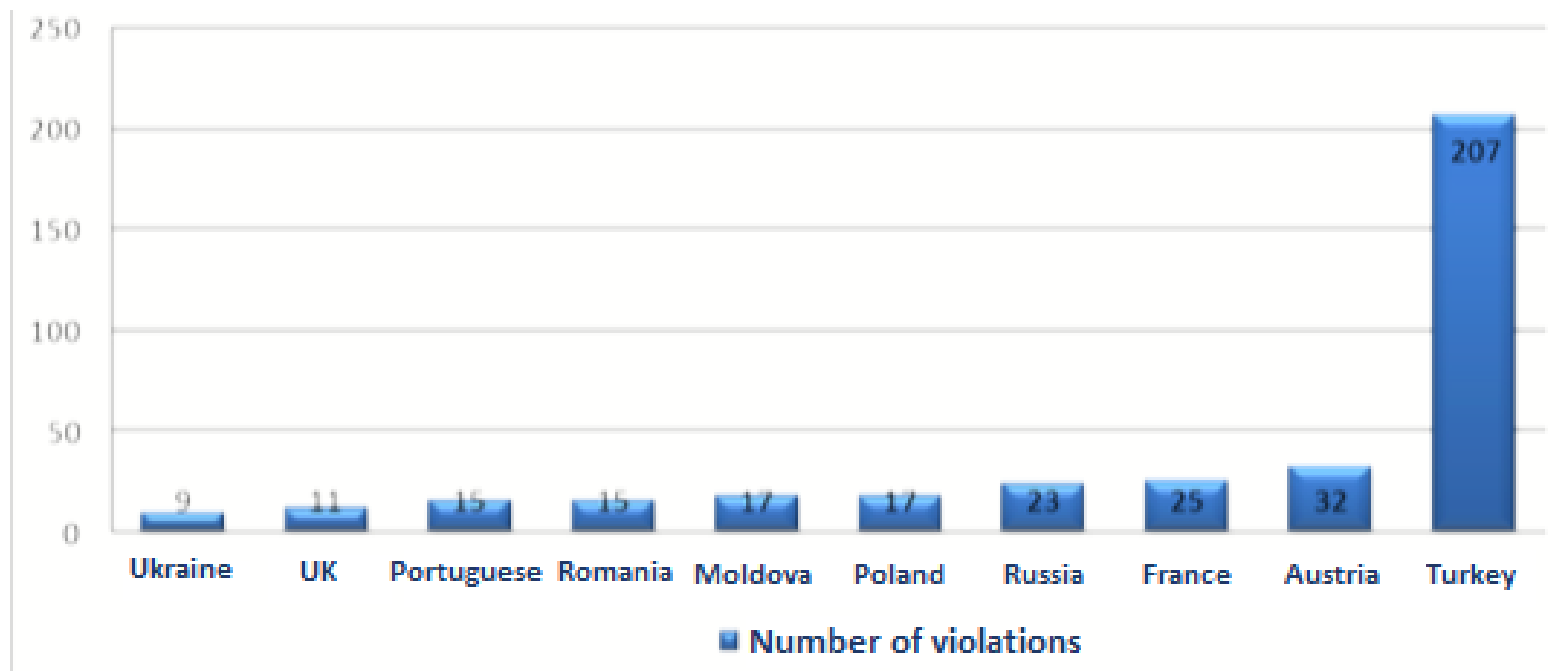

Figure 8. The numeric distribution of ECHR decisions on freedom of expression by countries, 19592011

However, one should take the issue of resolution of conditions into consideration in order to be able to interpret these data. It is clear that freedom of expression is one of the basic requirements of a democratic society. The development of individuals, groups and, most importantly, societies is related to the existence of different ideas, but freedom of expression, like all freedoms, is not unlimited. Of course, this restriction arises from the fact that the bearer of the freedom, in a philosophical sense, is "human;" thus, the restriction is imposed based on various criteria. The reason for determining these criteria is to prevent arbitrariness. Based upon the basic human rights documents, the limitation criteria are listed as follows:

\footnotetext{
${ }^{50} \mathrm{http} / / /$ www.inhak.adalet.gov.tr/istatistikler/2011_ist/01.pdf (Date of access: 10 May 2012)
} 
"Respect of the rights or freedoms or reputations of others," "the protection of the rights and freedoms of others," "the protection of national security, public order, public health, moral, public welfare, public safety," "the prevention of disorder or crime," "preventing the disclosure of information received in confidence," "maintaining the authority and impartiality of the judiciary," "the protection of territorial integrity," "the protection of privacy," "the protection of the economic wellbeing of the country," "guaranteeing the payment of taxes or other affiliates and penalties," "requirement of justice," “community service reason," "moral protection of childhood and adolescence."

It should be kept in mind that these restrictions also have a limit. The main reason for placing restrictions on freedom of expression that separates a democratic society from a totalitarian society is to ensure that freedom is enjoyed public-wide, and, most importantly, to prevent abuse (Erdem, 1998/1:5-36).

States fighting against terrorism like Turkey, on the one hand, restrict the scope of freedoms to prevent terrorism, on the other hand, they impose various restrictions and limitations to prevent terrorist groups from spreading their own ideas and perverse ideologies into society; because terrorism aims at achieving its non-legitimate purposes by using the broad areas of action which are formed by concepts such as democracy, freedom and human rights. For this reason, in order to construct human rights, to prevent violations and to form a modern and democratic structure; placing restrictions on rights and freedoms in accordance with validity, proportionality, the words and spirit of the constitutions, and the requirements of democratic society is fundamental to the protection of human rights.

\section{References}

Akyol H. (2010). Kürt Medyasında Yirmi Y1l, Istanbul: Evrensel Basın Yayın

Anar E. (1999). İnsan Hakları, Ankara: Maki Basın Yayın

Aybay R. (2010). İnsan Hakları Seçilmiş Makaleler, Istanbul: Pencere Yayınları

Çotuksöken B. (2010). İnsan Hakları ve Felsefe, Istanbul: Papatya Yayıncılık

Doğru O. (1998). İnsan Hakları Uluslararası Mevzuatı, Istanbul: Beta Yayınları

Doğru O. Nalbant A. (2000). İnsan Hakları Avrupa Mahkemesi ve Türkiye Karar Özetleri (1995-2000), Istanbul: İstanbul Barosu Yayınları

Donelly J. (1989). Teoride ve Uygulamada Evrensel İnsan Hakları, Ankara: Yetkin Yayınları

Durul F. (1998). Küreselleşme ve İnsan Hakları, Istanbul: Toroslu Yayıncılık

Erdem F.H. (1998). In Ankara Barosu Dergisi, Düşünce Özgürlüğü ve Demokrasi, vol: 55, Ankara, 1998/1, pg.5-36

Erdoğan M. (2007). İnsan Hakları Teorisi ve Hukuku, Ankara: Orion Kitabevi

Ergül E. (2004). Avrupa İnsan Hakları Mahkemesi ve Uygulaması, Ankara: Yargı Yayınları

Frowein, A.F. (1992). İnsan Haklarının Çağdaş Yorumu. In Anayasa Yargısı Dergisi, Vol No: 9, Ankara: pg.111-115 
Gemalmaz S. (2001). Ulusalüstü İnsan Hakları Hukukunun Genel Teorisine Giriș, Istanbul: Beta Yayınları

Gemalmaz S.( 2010). Ulusalüstü İnsan Hakları Hukukunun Genel Teorisine Giriş, Istanbul: Legal Yayınları

Gülmez M. (2001). İnsan Hakları ve Demokrasi Eğitimi, Ankara: TODAİE

Güneș S. (1998), “İșkence, Eziyet ve İnsan Onuruyla Bağdaşmayan Muamele Yasağg”, Yeni Türkiye Dergisi, Vol. 22, Ankara: pg.915- 923

Kapani M. (1976). Kamu Hürriyetleri, Ankara: Ankara Üniversitesi Hukuk Fakültesi Yayınları

Kuçuradi İ. (2004). Felsefe ve İnsan Hakları, Ankara: Türkiye Bilimler Akademisi

Özbey Ö. (2008). Avrupa İnsan Hakları Mahkemesine Başvuru Yöntemleri, Ankara: Adalet Yayınları

Özdek Y. (2004), Avrupa İnsan Hakları Hukuku ve Türkiye, TODAİE, ed.321, Ankara: pg. $265-273$

Reisoğlu S. (2001). Uluslararası Boyutlarıyla İnsan Hakları, Istanbul: Beta Yayınları

Tanrıkulu S. (2007). İnsan Hakları Avrupa Mahkemesi’ne Bireysel Başvuru İçin El Kitabı, Istanbul: Seckin Yayınları

Tezcan D.(2006). İnsan Hakları El Kitabı, Ankara: Seckin Yayınlar

Ünal Ş. (1997). Temel Hak ve Özgürlükler ve İnsan Hakları Hukuku, Ankara: Yetkin Yayınları

Uygun O. (2000). İnsan Hakları Kuramı, Ankara: Yapı Kredi Yayınları

http://hudoc.echr.coe.int/sites/eng/Pages/search.aspx

http://www.inhak.adalet.gov.tr/mevzuat/mevzuat.html

http://www.istanbul.edu.tr/idarehukuku/belgeler/fransizyurttashaklaribil- dirisi.pdf

http://www.ihb.gov.tr/Yayinlarimiz/insan_haklari_kitabi_LOW.pdf (Date of Access: 11 November 2008)

http://www.dusuncetarihi.com/makale/dort-ozgurluk-soeylevi (Date of Access: 11 January 2011)

http://www.ikincigrup.com/index.asp?haberID=28462 (Date of Access:24.08.2011)

http://www.tbmm.gov.tr/komisyon/insanhaklari/pdf01/3-30.pdf

http://www.un.org.tr/ (Date of Access: 24 March 2011)

http://www. belgenet.com/arsiv/bm/bmsiyasihak.html (Date of Access: 2 Ağustos 2011)

http:// www. belgenet.com/arsiv/bm/bmsiyasihak.html (Accessed on 2 August 2011)

http://www.belgenet.com/arsiv/bm/bmsiyasihak.html (Accessed on 2 August 2011)

http://www.unicef.org/turkey/cedaw/_gi18. html) (Accessed on 2 August 2011)

http://www.un.org/documents/ga/res/39/ a39r046.htm (Accessed on 2 August 2011)

http://www.tbmm.gov.tr/komisyon/insanhaklari/pdf01/137-160.pdf) (Accessed on 2 August 2011)

http://www1.umn.edu/humanrts/instree/12ptichr.htm (Accessed on 25 May 2012)

http://www.unhchr.ch/huridocda/huridoca.nsf/(symbol)/a.conf.157.23.en (Accessed on 18 April 2012)

http://www.mfa.gov.tr/avrupa-konseyi_tr.mfa (Accessed on 10.10.2012)

http://www.anayasa.gov.tr/files/bireysel_basvuru/AIHS_tr.pdf (Accessed on 21 March 2011) 
http://www.echr.coe.int/NR/rdonlyres/A6FDF170-5DA0-4F25-8017-

8D49A83681F0/0/TUR_50questions_Web.pdf (Date of Access:10.06.2011)

http://www.yargitay.gov.tr/abproje/belge/dagitim/66_Soruda_Bireysel_Bas-vvuru.pdf (Date of access: 01.09.2012)

http://www.ihb.gov.tr/dosyagoster.ashx?id=291 (Date of access: 29 Mayıs 2012)

http://www.inhak.adalet.gov.tr/istatistikler/2011_ist/03.pdf (Date of access: 25 March 2012)

http://www.hukukîhaber.net/ekonomi/2011-aihm-faturasi-37-milyon- tl-h23328.html (Date of access: 10 March 2012

http://www.inhak.adalet.gov.tr/istatistikler/2011_ist/04.pdf (Date of access: 19 May 2012)

http://echr.coe.int/Documents/Annual_report_2012_ENG.pdf

http://www.inhak.adalet.gov.tr/istatistikler/2011_ist/01.pdf (Date of access: 10 May 2012) 